KS. BOLESEAW KUMOR

\title{
OBSADA METROPOLII LWOWSKIEJ OBRZĄDKU ŁACIŃSKIEGO W LATACH 1772-I9I8
}

Zagadnienie obsady niektórych biskupstw obrządku lacińskiego w zaborze austriackim omawiałem dotąd w dwóch artykułach; jeden z nich poświęciłem biskupstwu krakowskiemu w latach niewoli narodowej i drukowałem go na łamach ,Analecta Cracoviensia” 1, drugi natomiast poświęciłem metropolii lwowskiej obrz. łac. w latach 1780-1850. Opracowanie to wygłosiłem jako referat na posiedzeniu Towarzystwa Naukowego Lubelskiego (22 I 1974). Ukazało się ono w druku w formie streszczenia w ,Folia Societatis Scientiarum Lublinensis” 2. Niniejsze opracowanie jest pełnym tekstem wspomnianego uprzednio referatu, a nadto zawiera opracowanie tego samego zagadnienia $w$ dalszych latach niewoli narodowej $1850-1918$.

Sprawa obsady metropolii lwowskiej i innych biskupstw w Galicji zainteresowała rządy zaborcze bardzo wcześnie. Już w 1774 r. gubernator Galicji hr. H. Auersperg przesłał w tej sprawie ankietę do metropolity lwowskiego W. H. Sierakowskiego i biskupa przemyskiego J. T. Kierskiego. W ankiecie tej gubernator zapytywał: czy biskupi w Polsce byli wybierani przez kapituły, a w wypadku wyborów kapitulnych, czy asystował przy wyborach urzędnik królewski i jaką formę miała ta asystencja w wypadku nominacji królewskiej - jaką przybierała ona formę; kto zajmował się administracją dóbr arcybiskupstwa po śmierci metropolity i jakie legaty otrzymuje katedra metropolitalna po jego śmierci. Odpowiedź na ankiete przesłał metropolita w dniu 5 IV 1774 r., a biskup przemyski - 26 III 1774 r. Informowały one zgodnie, że król polski mianował metropolitę lub biskupa, a kapituła wybierała nominata królewskiego. Majątek mensy biskupiej oddawano elektowi dopie-

1 B. Kumor, Obsada biskupstwa krakowskiego w latach 1790-1914, ,Analecta Cracoviensia" 8 (1976) s. $321-343$.

2 B. Kumor, Obsada metropolii lwowskiej obrzqdku lacińskiego w latach 17801850, „Folia Societatis Scientiarum Lublinensis” 18 (1976) Hum. 2 s. 95-105. 
ro po nadejściu bull papieskich, a w czasie wakansu zarząd dóbr należał do kapituły. Katedry nie otrzymywały po śmierci biskupów żadnych legatów, chyba że były one testamentalnie przekazane przez zmarłych ordynariuszów ${ }^{3}$.

Wiadomość o chorobie metropolity lwowskiego W. H. Sierakowskiego, o której donosił on do Wiednia w dniu 19 VI 1777 r., wywołała we Wiedniu pewne zakłopotanie. W związku z tym gubernator Galicji hr. Auersperg otrzymał w dniu 28 XII 1776 r. polecenie rządowe, żeby w skrytości i bez budzenia podejrzenia dowiedział się, w jaki sposób odbywały się wybory biskupów w Polsce, a przede wszystkim arcybiskupa lwowskiego i przemyskiego biskupa. Z tego polecenia gubernator wywiązał się stosunkowo szybko, bo już w dniu 12 II 1777 r. przesłał cesarzowej Marii Teresie bardzo obszerne sprawozdanie na ten temat, obejmujące 48 stron in folio. Tak szybkie załatwienie tej sprawy należy tłumaczyć tym, że hr. Auersperg miał już gotowe relacje na ten temat z r. 1774 tak od arcybiskupa lwowskiego, jak i od biskupa przemyskiego.

Wnioski gubernatora $\mathrm{z}$ przesłanych relacji były jasne: cesarzowa $\mathrm{Ma-}$ ria Teresa miała wejść w prawa kolatorskie króla polskiego i mianować zarówno metropolitę, jak i innych biskupów w Galicji. Nominacja cesarska miała być dostarczona kapitułom za pośrednictwem delegata rządowego. Sugestie te w pełni akceptowała kancelaria czesko-austriacka; we wniosku z dnia 7 III 1777 r. radca dworski F. J. Heinke zalecał utrzymanie „wyborów kapitulnych”, które w ,niczym nie ograniczają praw zwierzchnich". W odpowiedzi na przedłożony wniosek cesarzowa Maria Teresa zadecydowała: ,ponieważ Królestwa Galicji i Lodomerii zostały przeze mnie rewindykowane jako oderwane części Królestwa Węgierskiego, przeto należy tam w sprawach kościelnych wykonywać wszystkie prawa króla apostolskiego we wszystkich wypadkach podobnie jak na Węgrzech; do tego winna się stosować ściśle kancelaria i gubernium" (22 II 1777 r.) ${ }^{4}$. Oznaczało to, że cesarzowa i jej następcy mają pełne prawa prezenty i patronatu w stosunku do biskupstw katolickich w Galicji.

Radca nadwornej kancelarii F. J. Heinke w memoriale z października 1787 r., złożonym na ręce cesarza Józefa II, postawił tezę, że cesarz może nawet bez zgody Rzymu mianować metropolitów i biskupów

3 Allg. Verw. Wien (Allgemeines Verwaltungsarchiv. Wien) Alte Kultus Akten. 33. Fasc. 133. Nr 23 ex Junio 1779 (Abp W. H. Sierakowski do Gubernium - 5 IV 1774; Bp J. T. Kierski do Gubernium - 26 III 1774).

4 Tamże. Nr 23 ex Junio 1779 (gubernator Auersperg do Nadwornej Kancelarii - 12 II 1777; wniosek Kancelarii Nadwornej do cesarzowej Marii Teresy 7 III 1777; decyzja Marii Teresy - 23 III 1777; Kancelaria Nadworna do Gubernium galicyjskiego - 22 III 1777); por. W. Chotkowski, Historia polityczna Kościoła w Galicji za rzqdów Marii Teresy. T. 1, Kraków 1909, s. 384-396. 
i przekazywać im zarząd kościelny w diecezji in temporalibus (dobra) oraz in spiritualibus (jurysdykcja kościelna) ${ }^{5}$. Taką też postawę przyjęli cesarze austriaccy w zakresie nominacji metropolitów i biskupów. Opór Stolicy Apostolskiej łamano faktami dokonanymi, jak to miało miejsce w wypadku obsady stolicy metropolitalnej w Lublianie (1787). Prawo nominacji na nowo utworzone biskupstwo tarnowskie (1786) otrzymali władcy Austrii w bulli erekcyjnej diecezji z 13 III 1786 r., dane im przez papieża Piusa VI i potwierdzone nieco później przy reerekcji tejże diecezji w dniu 20 IX 1821 r. przez Piusa VII ${ }^{6}$. Podobnie decydował cesarz o nominacji hierarchów unickich, a bulla Piusa VIi In universali Ecclesiae $\mathrm{z}$ dnia 22 II $1807 \mathrm{r}$. przyznawała $\mathrm{mu}$ to prawo w odniesieniu do nominacji ordynariuszów w Przemyślu i Chełmie oraz metropolity lwowskiego obrządku grecko-katolickiego ${ }^{7}$. Najpóźniej uzyskał cesarz prawo nominacji arcybiskupa metropolity obrządku ormiańskiego. Do uregulowania tej sprawy doszło dopiero po śmierci arcybi-skupa Stefanowicza (3 X 1816). Na mocy bulli Inter caetera privilegia z 20 IX 1819 r. Pius VII przyznał cesarzowi austriackiemu prawo nominacji arcybiskupa, ale spośród trzech kandydatów przedstawionych mu przez kler ormiański Lwowa. Nominata cesarskiego miała przedstawiać do prekonizacji papieskiej Kongregacja Rozkrzewiania Wiary. W oparciu o te przepisy nastąpiła elekcja (lipiec 1817), nominacja (17 XI 1819) i prekonizacja (21 II 1820) arcybiskupa Kajetana Wartasiewicza $(1820-1831)^{8}$.

Kandydatów na stolice metropolitalną i biskupią w Galicji wysuwało Gubernium we Lwowie. Przypomnieć należy, że w latach schyłkowego józefinizmu kandydatów na wakujące biskupstwa wysuwali nadio metropolita i inni biskupi ordynariusze. Ostateczną listę kandydatów formowała rada gubernialna i wraz z opiniami i personaliami kandydatów wysyłała do Wiednia. Do 1848 r. sprawami nominacji biskupów zajmowała się Nadworna Komisja Duchowa lub Kancelaria Nadworna. Komisja układała ostateczną listę kandydatów i wraz z opinią własną i gubernialną przesyłała ją cesarzowi. Dopiero teraz następowała nominacja cesarska i jej ogłoszenie. W wypadkach pozytywnych ustaleń następowała nominacja cesarska, ale jej ogłoszenie publiczne następowało

5 F. Maass, Der Josephinismus. Quellen zu seiner Geschichte in Österreich 1760-1790. Bd. $3 \mathrm{nr} 11$ s. 402-421 (październik 1787), nr 12 s. 422 -444 (koniec 1787 r.).

${ }_{6}$ B. Kumor, Dzieje polityczno-geograficzne diecezji tarnowskiej, Lublin 1958, s. 124 (1786), 158 (1821).

7 Documenta Pontificum Romanorum historiam Ucrainae illustrantia (10751953). T. 2 (1700-1953), Romae 1954, s. 313-319 (nr 871).

$\checkmark$ HHSt. Wien Haus- Hof- und Staatsarchiv. Wien) aussen Abt. 2264/1892 (relacja na temat obsady arcybiskupstwa obrządku ormiańskiego we Lwowie); Bull. Rom. Cont. t. 15. Romae 1853 nr 891 s. $249-250$. 
dopiero później. Nominat zwracał się do nuncjusza apostolskiego w Wiedniu o przeprowadzenie procesu informacyjnego, a do ambasady austriackiej przy Watykanie o dopilnowanie sprawy prekonizacji na najbliższym konsystorzu papieskim. W ciągu trzech miesięcy po prekonizacji, zgodnie z przepisami Soboru Trydenckiego (Sessio XXIII cap. 2) winna się odbyć konsekracja kandydata, jeżeli nie miał sakry biskupiej. $\mathrm{Z}$ chwilą prekonizacji metropolity lub biskupa ordynariusza papiez w każdym wypadku wysyłał specjalną bullę powiadamiającą do cesarza. $Z$ reguły była to bulla Gratiae divinae proemium ${ }^{9}$. Tak też w zasadzie odbywał się proces nominacji i prekonizacji metropolitów lwowskich i biskupów galicyjskich. Przypatrzmy się bliżej tym nominacjom, a jest to tym łatwiejsze, że dysponujemy bogatymi materiałami źródłowymi z archiwów panstwowych Wiednia i Rzymu dla całego omawianego okresti.

$\mathrm{Na}$ wstępie należy zaznaczyć, że polityka kościelna Austrii w stosunku do obsady biskupstw, a zwłaszcza metropolii we Lwowie, różniła się zasadniczo od polityki kościelnej Prus w stosunku do Gniezna czy polityki Rosji w stosunku do Mohylowa i Warszawy. Ale było to uzasadnione. Austria była przecież monarchią katolicką. Te różnice uzewnętrzniły się w bardzo krótkich wakansach stolicy metropolitalnej we Lwowie. Wakanse w Gnieźnie - Poznaniu, Warszawie i Mohylowie w omawianym okresie trwały łącznie dziesiątki lat, a w wypadku Warszawy sięgały 50 lat. Tymczasem wakanse stolicy metropolitalnej we Lwowie w latach 1772-1918 trwały ogółem zaledwie około 11 lat na łączną liczbę 10 wakansów, przy czym najdłuższy wakans od 18 I 1812 do 15 II 1815 r. był spowodowany nieprzyjęciem nominacji przez dwóch nominatów.

Pierwszy wakans stolicy metropolitalnej we Lwowie pod rządami austriackimi nastąpił po śmierci zasłużonego i bardzo czynnego duszpastersko metropolity Wacława Hieronima Sierakowskiego (25 X 1780). Ale rządy austriackie uprzedziły wakans stolicy metropolitalnej przez narzucenie abpowi Sierakowskiemu koadiutora $z$ prawem następstwa w osobie ks. Ferdynanda Kickiego. Sprawa ta była o tyle delikatna, że prawa patronackie do metropolii należały do króla polskiego i jemu przysługiwało prawo nominacji, dlatego rządom austriackim zależało na uprzednim wyznaczeniu koadiutora. Był to pierwszy wypadek nominacji na biskupstwo polskie przez zaborcze władze austriackie. Jeszcze w 1776 r. metropolita Sierakowski mianował swoim biskupem pomocniczym ks. Ferdynanda Kickiego, prepozyta kapituły metropolitalnej we Lwowie, którego ostatecznie władze austriackie uznały (20 VI 1777).

9 HHSt. Wien. Aussen Abt. XL 248. P. A. Interna LX/120 (elaborat na temat obsady biskupstw w monarchii austriackiej). 
Kandydature ks. Kickiego na koadiutora z prawem następstwa poparła wydatnie kapituła metropolitalna w liście z 17 I 1778 r. do cesarzowej Marii Teresy ${ }^{10}$. Tego też kandydata Maria Teresa, mimo oporu metropolity Sierakowskiego, narzuciła na koadiutora $z$ prawem następstwa (18 IV 1778). Był to jedyny kandydat, ,, po którego energicznej działalności spodziewano się wykonania dzieła i który innym biskupom na razie będzie mógł przykładem świecić”. Miał to być więc metropolita podatny na reformy józefińskie. Nuncjusz apostolski we Wiedniu Józef Garampi, który w dniu 22 VI 1778 r. otrzymał polecenie przeprowadzenia procesu informacyjnego ks. Kickiego, wysyłajac akta procesu do Rzymu (13 VIII 1778), zwracał uwagę papieża i sekretarza stanu, że jest. to pierwszy wypadek nominacji cesarzowej na biskupstwo w Galicji, która to nominacja przysługuje królowi polskiemu. Sugerował więc, aby w bulli prekonizacyjnej dla ks. Kickiego wyraźnie zaznaczono o indulcie papieskim na tę nominację. Stąd to mimo zabiegów dworu austriackiego w bulli prekonizacyjnej z dnia 20 IV $1778 \mathrm{r}$. dla ks. Kickiego opuszczono wzmiankę o prezencie i nominacji cesarzowej, a w bulli Gratiae divinae proemium, skierowanej przy tej okazji do Marii Teresy, papież Pius VI użył wprost wyrażenia, że koadiutora stałego on sam ustanowil i wyznaczył (,,coadiutorem perpetuum constituimus deputamus"). To stanowisko kurii papieskiej nie podobało się w Wiedniu, ale w Rzymie nie protestowano. Sprawa bowiem ze względu na prawa króla polskiego była zbyt delikatna. Ograniczono się tylko do tego, ze w placetum regium dla bulli zaznaczono, iż ,Najjaśniejsza Pani na podstawie najwyższych praw monarszych raczyła go mianować koadiutorem metropolity lwowskiego". Dnia 25 X 1780 r. po śmierci metropolity Sierakowskiego arcybiskup K. Kicki przejął rządy w archidiecezji lwowskiej ${ }^{11}$.

Trudności tego rodzaju zanikły zupełnie przy obsadzaniu stolicy metropolitalnej w r. 1797. Od dwóch lat nie istniało już państwo polskie, a na obszary ziem polskich, zwłaszcza pierwszego zaboru, przyzwyczajono się w Europie patrzeć jako na tereny przynależne do państw zaborczych. Po śmierci metropolity Ferdynanda Kickiego (2 II 1797) ${ }^{12}$, cesarz Franciszek II potwierdził w dniu 17 II 1797 r. wybór biskupa po-

10 Allg. Verw. Wien. Alte Kultus Akten 33. Fasc. 135 Erzbisthum Lemberg. Nr 51 ex Martio 1778 (Kapituła lwowska do cesarzowej Marii Teresy — 17 I 1778).

11 Allg. Verw. Wien. Alte Kultus Akten 33. Fasc. $50 \mathrm{nr} 51$ ex Martio 1778 (gubernator Auersperg do Nadwornej Kancelarii - 8 II 1778) Nr 100 ex Junio 1777 (dokumenty związane z nominacją na biskupa pomocniczego); nr 51 ex Martio 1778, nr 79 ex Februario 1779, nr 89 ex Decembre 1779 (dokumenty związane z nominacją na koadiutora, kopie bull papieskich); W. Chotkowski, jw., s. $398 \mathrm{nn}$.; Hierarchia catholica medii et recentioris aevi. Vol. 6. Patavii 1958, s. 259.

${ }_{12} \mathrm{Cz}$. Lechicki, Kicki Ferdynand Onufry, [w:] Polski Słownik Biograficzny 12 s. $387-388$. 
mocniczego Kajetana Ignacego Kickiego, bratanka zmarłego metropolity, na urzędzie wikariusza kapitulnego. Jego też kandydaturę na wakujące arcybiskupstwo poparło nad wyraz mocno Gubernium lwowskie. O stanowisko to zresztą zabiegał on sam. W specjalnej petycji, skierowanej do tegoż Gubernium, bp K. I. Kicki podkreślał, że jako dyrektor Wydziału Teologicznego na Uniwersytecie Lwowskim posiada odpowiednią wiedzę teologiczną, zaś jako od 10 lat wikariusz generalny archidiecezji zdobył odpowiednie doświadczenie w zarządzaniu archidiecezją. Jego pozytywną postawę moralną, kościelną i obywatelską zalecały nadto specjalne listy polecające abpa obrządku ormiańskiego Jakuba Tumanowicza i biskupów obrządku gr.-kat. P. Bielańskiego ze Lwowa i A. Angełłowicza z Przemyśla. Warto zwrócić uwagę, że takich listów polecających nie wystawili biskupi obrządku łacińskiego z Przemyśla A. Gołaszewski i z Tarnowa F. A. Janowski. Ale było to zrozumiałe choćby z tej przyczyny, że zapewne obydwaj czuli się kandydatami na wakująca stolicę metropolitalną.

Osobę bpa K. I. Kickiego poparła - rzecz dziwna nieco i później nie praktykowana - w osobnych listach polecających do cesarza magnateria galicyjska i mieszczaństwo lwowskie, a nade wszystko Gubernium galicyjskie, które wysunęło jedynie jego kandydaturę. W dniu 4 III $1797 \mathrm{r}$. Directorium in cameralibus et publico-politicis w Wiedniu we wniosku do ces. Franciszka II stwierdzało m. in.:

$1^{\circ}$ Prezentacja na wakujące arcybiskupstwo lwowskie zależna jest wyłącznie od cesarza jako prawowitego patrona archidiecezji. Dyrektorium wysuwa jako jedynego kandydata na to stanowisko biskupa popocniczego K. I. Kickiego, popieranego przez Gubernium galicyjskie.

$2^{\circ}$ Poza bpem K. I. Kickim nikt inny nie ubiega się o stolicę metropolitalną we Lwowie, sam zaś kandydat rządził już przez pewien czas faktycznie archidiecezją lwowską, ponieważ zmarły metropolita F. Kicki był chorowity i stary.

$3^{\circ}$ Bp K. I. Kicki został przez ces. Leopolda II mianowany członkiem wschodnio-galicyjskiej Komisji Duchownej i od 1790 r. prowadzi bardzo dobrze agendy Wydziału Teologicznego we Lwowie, jako jego dyrektor.

$4^{\circ}$ Według opinii gubernialnej, ,jest on dla chorych i biednych ojcem i proboszczem". Przytoczono też opinie wspomnianych biskupów galicyjskich, magnaterii i mieszczaństwa lwowskiego.

Tę też kandydaturę zaakceptował cesarz w dniu 17 IX 1797 r. i zamianował arcybiskupem metropolitą lwowskim dotychczasowego bisku-

13 Allg. Verw. Wien. Alte Kultus Akten 33. Fasc. 135 Erzbisthum Lemberg. $\mathrm{Nr} 126$ ex Majo 1797 (wniosek Directorii in cameralibus - 4 III 1797); nr 180 ex Junio 1797 (koncept dekretu nominacyjnego); nr 175 ex Februario 1798 (kopie bull papieskich). 
pa pomocniczego lwowskiego K. I. Kickiego, którego prekonizował na to stanowisko papież Pius VI bullą Romani Pontificis z 18 XII 1797 r. ${ }^{13}$ Rządził on archidiecezją lwowską do 1812 r. ${ }^{14}$

Od 1812 r. polityka kościelna Austrii w stosunku do obsady metropolii we Lwowie i biskupstw w Galicji, zgodnie z zasadami konserwatyzmu i wzrostem tendencji unifikacyjnych i germanizacyjnych w różnonarodowym Cesarstwie Austriackim, popierała wydatnie Niemców i zniemczonych Czechów. Dotyczyło to zarówno obsady najwyższych urzędów kościelnych, jak i kapituł katedralnych, rektoratów seminariów duchownych, urzędów konsystorskich, probostw itp. Taki system polityki kościelnej w Wiedniu, zwłaszcza do najwyższego urzędu kościelnego w Galicji, jakim była metropolia lwowska, trwał aż do 1848 r. i załamał się gwałtownie w czasie Wiosny Ludów. W okresie tym przy obsadzaniu stolicy metropolitalnej we Lwowie główną rolę odgrywała nadworna kancelaria cesarska w Wiedniu. Kandydatów Gubernium lwowskiego nie zawsze brano pod uwagę.

Tendencje te wystąpiły z całą jaskrawością już w $1812 \mathrm{r}$. przy obsadzie metropolii lwowskiej po śmierci arcybiskupa K. I. Kickiego (12 I 1812). Lista Gebernium lwowskiego, podkreślająca ,pochodzenie narodowe", wystawiona przed 20 VI 1812 r., wysunęła 4 kandydatury: biskupa przemyskiego Antoniego Gołaszewskiego, nowomianowanego biskupa Hradec Kralove w Czechach A. J. Krakovsky-Kolowrata, biskupa pomocniczego Passawy hr. K. J. von Gaisrucka, oraz wikariusza kapitulnego i prepozyta kapituły metropolitalnej lwowskiej ks. Jana Hoffmana. Ale tylko biskup Gołaszewski był Polakiem, podczas gdy drugi i ostatni byli zniemczonymi Czechami, a trzeci $\mathrm{z}$ nich był Niemcem. Przy kandydaturze biskupa A. J. Krakovsky-Kolowrata Gubernium załączyło notę, że ,doszło do przekonania, iż ten raczej nie”, dlatego jego kandydaturę postawiono na drugim miejscu.

Tymczasem kancelaria nadworna na posiedzeniu w dniu 31 XII 1812 roku wprawdzie akceptowała kandydaturę bpa Gołaszewskiego, ale zwracała uwagę na młodego i energicznego rektora Akademii Teologicznej w Ołomuńcu i kanonika tamtejszej kapituły metropolitalnej, ks. Andrzeja Alojzego Skarbka z Posławic Ankwicza. Był to krakowianin wychowany we Wiedniu, Polak, przyszły odnowiciel życia religijnego w archidiecezji lwowskiej i według E. Wintera ,repolonizator Galicji”. Wymieniono nadto wikariusza generalnego z czeskich Budziejowic ks. Kuńczyka. Ale ostateczna lista kandydatów przedstawiona cesarzowi Franciszkowi I przez kancelarię nadworną była jeszcze inna i obejmowała 5 nazwisk biskupów czeskich i austriackich, wyłącznie Czechów i Niemców.

14 Cz. Lechicki, jw., s. 389. 
Byli to więc według kolejności: (1) biskup Litomierzyc w Czechach Wacław Leopold Chlumczansky, (2) książę biskup Lwanatu Leopold Maksymilian von Firmian, (3) biskup Hradec Kralove A. J. Krakovsky-Kolowrat, (4) biskup Czeskich Budziejowic hr. J. P. von Schaffgotsch oraz (5) biskup Brna Morawskiego ks. Wincenty Józef von Schratenbach.

$\mathrm{Na}$ tej liście znalazł się tylko jeden kandydat wysunięty przez Gubernium galicyjskie - biskup Kolowrat, zamieszczony na trzecim miejscu. Franciszek I najwyższym postanowieniem z dnia 1 III 1813 r. mianował metropolitą lwowskim biskupa Litomierzyc W. L. Chlumezansky'ego ${ }^{15}$. Była to pierwsza nominacja obcokrajowca na stolice metropolitalną we Lwowie, na której od początku wyłącznie zasiadali Polacy. Kimże był nowy nominat? Był to zniemczony Czech (ur. 1749); doktorat $z$ filozofii uzyskał na Uniwersytecie w Pradze. Jako kanonik metropolitalny praski (od 1784) przez 11 lat był kaznodzieją niemieckim w archikatedrze św. Wita na Hradczanach. Jako biskup pomocniczy praski (1795-1802) przysłużył się wielce około rozbudowy szkolnictwa, ale zdaniem E. Wintera należał do zdecydowanych zwolenników kościelnego reżymu józefińskiego. W latach 1802-1814 był biskupem litomierzyckim, gdzie stworzył silny ośrodek józefiński. Nieco później, gdy był już na stanowisku metropolity praskiego, nuncjusz apostolski A. G. Severoli wysunął sugestię poufną, aby go usunąć z tego stanowiska (1821) ${ }^{16}$.

Wraz z nominacją na metropolitę lwowskiego W. L. Chlumezansky miał otrzymać uprawnienia wikariusza generalnego dla galicyjskiej części diecezji krakowskiej. W dniu 11 III 1813 r. powiadomiono biskupa Chlumczansky'ego i Gubernium galicyjskie o nominacji. Została ona przyjęta, ale ze względu na wojny napoleońskie nominat przebywał nadal w Litomierzycach. Wprawdzie 1 VII 1813 r. kancelaria nadworna złożyła wniosek u cesarza „o wprowadzenie w życie najwyższej nominacji na metropolię lwowską", a 1 III t.r. Franciszek I zalecał nominatowi przejęcie jurysdykcji kościelnej w galicyjskiej części diecezji krakowskiej, to ostatecznie nuncjatura wiedeńska procesu informacyjnego nie przeprowadziła, a w konsekwencji nie nastąpiła prekonizacja papieska. Papieża zresztą w Rzymie nie było, jako że Pius VII od 1809 r. przebywał na deportacji we Francji, a po 1811 r. w odosobnieniu pod Paryżem na zamku Fontainebleau. Nie jest wykluczone, że powiew odrodzenia narodowego, wywołany wojnami napoleońskimi i niepewność

15 Allg. Verw. Wien, Alte Kultus Akten. 33 Fasc. 135 Erzbisthum Lemberg. Nr 153 ex Decembri 1813 (wniosek Kancelarii Nadwornej - 31 XII 1812; decyzja cesarza Franciszka I - 4 III 1813); nr 153 ex Decembri 1813 (wniosek Kancelarii Nadwornej - 1 VII 1813); nr 18 ex Martio 1813 (Franciszek I mianuje bpa Chlumczansky'ego metropolitą we Lwowie - 12 III 1813).

1; E. Winter, Des Josefinismus und seine Geschichte. Beiträge zur Geistesgeschichte Ósterreichs 1740-1848, Brünn 1943, s. 337; Praha šest set let Cirkevni metropoli, Praha 1944, s. 105. 
Austrii przy utrzymaniu się w Galicji spowodowały, że biskup Chlumczansky przed 1 VII 1813 r. zrezygnował $\mathrm{z}$ arcybiskupstwa lwowskiego ${ }^{17}$. Zresztą otwarły się dlań perspektywy osiągnięcia metropolii praskiej w Czechach, którą też otrzymał w nominacji cesarskiej w dniu 30 XII 1814 r. (prekonizacja papieska - 15 III 1815) ${ }^{18}$.

Po niespodziewanej rezygnacji W. L. Chlumczansky'ego listę kandydatów na Lwów przygotowała sama kancelaria nadworna bez zasięgania opinii Gubernium galicyjskiego. Na liście tej, omawianej na posiedzeniu tejże kancelarii w dniu 1 VII 1813 r., zaproponowano tylko jedną kandydaturę księcia biskupa Chur i St. Gallen Karola Boul-Schauensteina (1794-1833). Jego nazwisko nie było na uprzedniej liście kandydatów. Był to Niemiec austriacki urodzony w Innsbrucku (1760); studiował w Collegium Germanicum w Rzymie i w 11 roku kapłaństwa został wybrany (22 I 1795), a następnie prekonizowany na biskupa w Chur (12 IX 1794) ${ }^{19}$. Jego też zamianował cesarz Franciszek I metropolitą lwowskim w dniu 18 VII 1813 r. Nominacja ta została przyjęta; w dniu 7 X 1813 r. nadworna kancelaria przekazała nowemu metropolicie lwowskiemu temporalia. Był to drugi z kolei obcy narodowo i narzucony przez rządy zaborcze metropolita na polskiej stolicy metropolitalnej w Galicji. Mimo braku prekonizacji papieskiej, bo takiej nigdy nie było, nowy metropolita, chociaż we Lwowie się nie pojawił, to jednak wydał w własnym imieniu kalendarz liturgiczny i schematyzm archidiecezji lwowskiej na rok $1814^{20}$.

Jeszcze przed rozpoczęciem procesu informacyjnego nominat zaczą zabiegać $\mathrm{w}$ dykasteriach rządowych o zatrzymanie dotychczasowego biskupstwa w Chur i prepozytury kolegiackiej SS. Piotra i Pawła na Wyszehradzie w Pradze. Taki zaś postulat był niemożliwy do przyjęcia przez józefińskie władze austriackie, które zdecydowanie zwalczały kumulację beneficjów kościelnych. Toteż po pewnej zwłoce kancelaria nadworna zażądała od niego ostatecznej deklaracji, a ta przyszła 8 III 1814 r. Nominat tłumaczył się, że bez zgody Stolicy Apostolskiej nie może opuścić dotychczasowej diecezji, a zgoda papieża w ówczesnych warunkach była prawie niemożliwa ze względu na jego osobistą sytuację. Toteż nominat zrezygnował z przyjętego już arcybiskupstwa we Lwowie, zaś kancelaria cesarska poleciła mu zwrócić 30 tys. florenów reńskich, przyjętych przezeń z tytułu nowego stanowiska. Rezygnację tę na wniosek Kance-

17 Allg. Verw. Wien. Alte Kultus Akten 33. Fasc. 135 Erzbisthum Lemberg. Nr 11 ex Julio 1813 - Zur Sitzung 1 VII 1813.

18 Hierarchia catholica, jw., vol. 7, Patavii 1968, s. 313 n.

19 Tamże s. 189.

20 Schematismus universi saecularis et regularis cleri archidioeceseos metropolitanae Leopoliensis rit. lat. 1814 Cels. Rev. Carolus comes Boul de Schauenstein S.R.I. Princeps episcopus Curiensis - - nominatus archiepiscopus metropolitanus Leopoliensis, Leopoli 1814. 
larii nadwornej (7 IV 1814) przyjął przebywający w Paryżu cesarz Franciszek I (23 V 1814) i zaakceptował zwrot wspomnianej kwoty; nadto polecił biskupowi Boul-Schauensteinowi natychmiast zrezygnować z prepozytury wyszehradzkiej ${ }^{21}$. Te stosunkowo surowe kroki absolutnego władcy Austrii były nie tylko wyrazem niezadowolenia z postawy księcia-biskupa z Chur, ale i z faktu, że Lwów nie miał szczęścia do niemieckich kandydatów.

Po rezygnacji biskupa Boul-Schauensteina listę kandydatów na metropolitę lwowskiego przygotowała znów sama kancelaria nadworna. Przedłożono ją cesarzowi w dniu 7 IV $1814 \mathrm{r}$. Tym razem obejmowała ona tylko 2 nazwiska: (1) biskupa przemyskiego A. J. Gołaszewskiego i (2) ks. A. A. Ankwicza, kanonika ołomunieckiego. Obaj kandydaci byli Polakami, co wskazuje pośrednio, że motywy narodowe mogły być przyczyną rezygnacji obydwóch poprzednich kandydatów. Przy kandydaturze biskupa Gołaszewskiego podkreślono jego osobistą pobożność i lojalność, ale wysunięto zastrzeżenie do jego wieku (miał wówczas 70 lat). Kandydaturę natomiast młodego ks. Ankwicza zalecały jego gorliwość religijna, duża inteligencja i młody wiek (36 lat). Jego też mianował 25 V 1814 r. cesarz metropolitą Lwowa, a papież Pius VII bullą Apostolatus officium z 15 III $1815 \mathrm{r}$. prekonizowal go na to stanowisko ${ }^{22}$. Był to krakowianin $\mathrm{z}$ urodzenia, syn straconego $\mathrm{w}$ powstaniu kościuszkowskim kasztelana sądeckiego Józefa (1794). Wychowany w Wiedniu pod opieką austriackiego biskupa polowego Z. Hohenwarta, uzyskał na Uniwersytecie Wiedeńskim doktorat $\mathrm{z}$ teologii (1810) i w tymże roku metropolita ołomuniecki Trautmansdorf mianował go kanonikiem kapituły metropolitalnej, dyrektorem Akademii Duchownej i rektorem seminarium duchownego w Ołomuńcu ${ }^{23}$. Był to niewątpliwie obok F. K. Wierzchlejskiego największy metropolita Lwowa w XIX stuleciu.

Po przeniesieniu metropolity Ankwicza do Pragi (1833) listę kandydatów na Lwów układała znów sama kancelaria nadworna we Wiedniu. Opinię Gubernium galicyjskiego pominięto. Lista z dnia 18 IX $1833 \mathrm{r}$. wymieniała tylko jednego kandydata: księcia biskupa Trydentu Fran-

21 Allg. Verw. Wien. Alte Kultus Akten 33. Fasc. 135 Erzbisthum Lemberg. Nr 9 ex Junio 1814 (bp Schauenstein do Kancelarii nadwornej - 8 III 1814; kancelaria nadworna do ces. Franciszka I - 7 IV 1814; Cesarz Franciszek I przyjmuje rezygnację - $23 \mathrm{~V}$ 1814). Die Entsagung des Fürstbischofs Chur Graffen BoulSchauenstein auf das Lemberger Erzbisthum nehme ich an, und will, dass die 30000 Flor. R., welche derselbe auf die Einkünfte dieses Erzbisthums bereiterhoben hat, von ihm zugleich zurückgefordet werden. Hiernach hat er aber von der Wischograd an den Leitmeiritzer Boschof Chlumczansky ohne weiters abzukommen.

${ }_{22}$ Tamże (wniosek kancelarii nadwornej - 7 IV 1814; nominacja cesarska $23 \mathrm{~V}$ 1814); nr 183 ex Decembri 1814 (dokumenty związane z przejęciem uposażenia arcybiskupstwa); nr 37 ex Junio 1815 (kopie bull papieskich); J. Umiński, Andrzej Alojzy Ankwicz, [w:] Polski Słownik Biograficzny 1 s. 115.

${ }_{23}$ Hierarchia catcholica, jw., vol. 7 s. 236; Praha šest set let, jw., s. 109 n. 
ciszka Ksawerego Luschina. On też został mianowany przez cesarza (18 III), a następnie bullą Romani Pontificis papieża Grzegorza XVI prekonizowany (22 VI 1834) na metropolitę lwowskiego ${ }^{24}$. Był to Niemiec austriacki z Karyntii (ur. 3 XII 1781), doktoryzował się na Uniwersytecie w Grazu (1813), a w latach 1806-1808 proboszczował w Klagenfurcie, zaś od $1820 \mathrm{r}$. był radcą gubernialnym w Innsbrucku. Mianowany 10 XI 1823 r. i prekonizowany przez papieża (24 V 1824) księciem biskupem Trydentu, duszpasterzował tu do 1834 r. ${ }^{25}$ Przeniesiony na metropolię do Lwowa czuł się tu źle, nie znał bowiem języka polskiego. Na pewno nie odpowiadała mu też atmosfera narodowa we Lwowie narastająca pod wpływem powstania listopadowego. To też w następnym roku (6 IV 1835) zrezygnował z urzędu metropolity lwowskiego i został przeniesiony na podobne stanowisko do Gorycji ${ }^{26}$.

Tym razem osobne listy kandydatów na wakującą stolicę metropolitalną we Lwowie przedstawili ustępujący arcybiskup Luschin i Gubernium galicyjskie. Był to pierwszy wypadek, że taką listę przedstawiał w swoim imieniu jeden $\mathrm{z}$ hierarchów galicyjskich. Lista ta obejmowała 7 nazwisk: 4 Polaków, 2 Czechów i 1 Niemca austriackiego. Byli to w kolejności zajmowanych miejsc: (1) ks. Franciszek Zachariasiewicz wikariusz kapitulny i kustosz kapituły lwowskiej, (2) ks. Antoni Lisiecki profesor Uniwersytetu Lwowskiego, (3) ks. Karol Mierzwiński scholastyk kapituły przemyskiej, (4) ks. Jan Hoffmann prepozyt kapituły lwowskiej, (5) biskup Michał Korczyński z Przemyśla, (6) biskup Franciszek Pištek z Tarnowa i (7) biskup Lubliany A. A. Wolf. Odnośnie kandydatur biskupów z Tarnowa i Przemyśla arcybiskup Luschin dodawal, że ,w sprawie tych dwóch biskupów nie chcę zabierać głosu, jako że są oni moimi współbraćmi i miałem zbyt mało czasu, aby ich lepiej poznać". Najbardziej zalecał na to stanowisko ks. F. Zachariasiewicza; pisał na jego temat: ,jestem przekonany, że nie tylko jest pełen sił (miał 63 lata), ale będzie bardzo godny jako biskup, by rządzić diecezją i w wypadku nominacji może okazać się dla archidiecezji lwowskiej bardzo pożyteczny". Odnośnie kandydatury biskupa Wolfa dodawał, że ta kandydatura ,,może się spotkać z trudnościami na tle narodowym" ${ }^{27}$. Czyżby i arcybiskup Luschin $z$ tych powodów odszedł ze Lwowa?

Lista gubernialna przedstawiona 25 III $1835 \mathrm{r}$. hr. Mitrovsky'emu była skromniejsza i zawierała tylko 2 kandydatury, a mianowicie: bi-

24 Allg. Verw. Wien. Alte Kultus Akten 33. Fasc. 135 Erzbisthum Lemberg. Nr VI/325 ex Novembri 1834 (dokumenty związane z nominacją abpa Luschina); nr VI/233 ex Augusto 1834 (kopie bull papieskich - 23 VI 1834).

${ }_{25}$ Hierarchia catholica, jw., vol. 7 s. 377.

26 Tamże, s. 203 (prekonizacja papieska 6 IV 1835).

27 Allg. Verw. Wien. Alte Kultus Akten 33. Fasc. 135 Erzbisthum Lemberg. Nr VI/194 Julii 1835 (abp Luschin do ces. Ferdynanda I - 3 II 1835). 
skupa F. Pišteka z Tarnowa i na drugim miejscu biskupa M. Korczyńskiego z Przemyśla. Dodano jednak, że w wypadku nominacji jednego z nich na Lwów, wówczas na wakującą stolicę biskupią w Tarnowie względnie w Przemyślu należy mianować ks. Zachariasiewicza albo ks. Karola Mierzwińskiego, scholastyka kapituły przemyskiej, lub też ks. F. Feygiela, prepozyta infułata tejże kapituły. Najlepszą wszakże opinię dano biskupowi Pištekowi i jego kandydaturę położono na pierwszym miejscu ${ }^{28}$. Tę listę kancelaria nadworna wzięła pod uwagę i w ternie przedstawionym cesarzowi Ferdynandowi I wysunęła na pierwsze miejsce biskupa Korczyńskiego, zaś na drugie - biskupa Pišteka, a na trzecie - ks. K. Mierzwińskiego (7 VII 1835). Wybór padł na jedynego kandydata cudzoziemca, biskupa Pišteka (24 VII 1835), którego też papież Grzegorz XVI bullą Romani Pontificis z 1 II 1836 r. prekonizował na metropolię lwowską. Był to piąty z kolei metropolita wybrany spoza kleru galicyjskiego, Czech z pochodzenia, dawny biskup pomocniczy praski (1824-1831), a następnie biskup tarnowski (1831-1836) ${ }^{29}$.

Stosunkowo długi wakans stolicy metropolitalnej po śmierci metropolity Pišteka (1 II 1846) przypadł na okres powstania narodowego, rzezi galicyjskiej i represji austriackich. Tłumione przez dłuższy czas uczucia narodowe i tym razem postanowiono zdusić i nie dopuścić na stolice metropolitalną do Lwowa Polaka. Nie wiadomo, jaki udział w obsadzie metropolii miał niechętny Polakom ówczesny gubernator Galicji hr. F. Stadion, a jaki jeszcze bardziej niechętny kanclerz Cesarstwa Austriackiego ks. K. W. L. Metternich. Wydaje się, że tym razem decydującą rolẹ odegrał ten ostatni. Brak bowiem gubernialnej listy kandydatów przemawia za takim wnioskiem. Lista kandydatów kancelarii nadwornej, przedstawiona Ferdynandowi I, wymieniała tylko jedno nazwisko; był to ks. Wacław Wilhelm Wacławiczek dziekan kapituły metropolitalnej w Pradze. A więc trzeci z kolei Czech, piąty cudzoziemiec, a szósty spoza kleru galicyjskiego. Wniosek został przyjęty i 18 VIII $1847 \mathrm{r}$. po przeszło półtorarocznym wakansie we Lwowie cesarz Ferdynand I zamianował ks. Wacławiczka metropolitą lwowskim. Nominacja została przyjęta (14 X 1847). Dnia 13 XI 1847 r. nominat złożył odpowiednią przysięge na wierność cesarzowi, a następnie odbył się pośpiesznie proces informacyjny i 17 XII 1847 r. papież Pius IX bullą Divina disponente clementia prekonizował go na metropolitę lwowskiego. Bulle prekonizacyjne otrzymały placet regium 5 III 1848 r., lecz zanim nominat otrzymał konsekrację, w Cesarstwie Austriackim wybuchła Wiosna Ludów. Centralistyczne pangermańskie rządy wiedeńskie zaczęły się

20 Tamże (gubernium do hr. Mircvsky'ego - 25 III 1835).

29 Tamże, Fasc. 135 Erzbisthum Lemberg. Nr 17845/2375 (wniosek Kancelarii Nadwornej — 4 VII 1835); nr 6775/837 (kopie bull papieskich). 
załamywać. Wiosna Ludów we Lwowie, która uzewnętrzniła falę głębokiego patriotyzmu również wśród duchowieństwa, przekonała władze austriackie i samego nominata, że objęcie przezeń stolicy metropolitalnej we Lwowie jest niemożliwe. W tych okolicznościach konsekracja ks. Wacławiczka została wstrzymana, a nominat, ,dobrowolnie i z własnej woli" zrezygnował $\mathrm{z}$ arcybiskupstwa lwowskiego w dniu $29 \mathrm{~V} 1848 \mathrm{r}$. ,z powodu wielkich trudności, w jakich znajduje się archidiecezja lwowska". Trzeba dodać, że trudności te były wyłącznie natury politycznej i narodowej. Tak kończył się okres narzucania przez władze austriackie metropolitów obcego pochodzenia do Lwowa. Sprawę rezygnacji ks. Waclawiczka przedstawiono nuncjaturze wiedeńskiej, która ją przesłała do Rzymu, gdzie też została przyjęta. Zabieg ten był konieczny ze względu na fakt, że ks. Wacławiczek był prekonizowany na metropolitę. Dnia 22 X 1848 r. kancelaria nadworna wystąpiła do cesarza z wnioskiem o podjęcie kroków w Rzymie celem uzyskania dla ks. Wacławiczka nominacji na arcybiskupa tytularnego in partibus infidelium; wniosek ten poparł już następny cesarz Franciszek Józef I (20 XII 1848). Ale Rzym takiej nominacji nie udzielił. Ks. Wacławiczek pozostał w Pradze, gdzie otrzymał niebawem prepozyturę kapituły metropolitalnej. Tam też zmarł w dniu 19 IX 1862 r.30

Nasze przypuszczenie na temat przyczyn rezygnacji ks. Wacławiczka w pełni potwierdza list hr. Stadiona, skierowany 24 III 1849 r. do Wiednia, w którym m. in. pisał, że ks. Wacławiczek ,na skutek wypadków marcowych w 1848 r. musiał być zdjęty z zajmowanego urzędu (,entheben”). W Galicji, jak pisał hr. Stadion ,partia narodowa nie czyni żadnych tajemnic ze swych celów i zamierzeń, a jej działalność popiera większa część kleru łacińskiego" 31. W tej sytuacji Gubernium galicyjskie wystąpiło z niezwykle frapującym wnioskiem, by metropolitą lwowskim ob. łac. zamianować arcybiskupa ormiańskiego ze Lwowa 93-letniego S. C. Stefanowicza i w jego osobie dokonać unii personalnej obydwóch archidiecezji. Arcybiskup Stefanowicz mógłby zamianować dwóch oddzielnych wikariuszów generalnych - jednego dla wiernych obrządku łacińskiego i drugiego dla obrządku ormiańskiego. Plan ten przesłany 30 XI 1848 r. do Wiednia podpisał gubernator Galicji W. Zaleski ${ }^{32}$.

Widocznie projekt ten nie znalazł żadnego uznania nad Dunajem, sko-ro niebawem zażądano od Gubernium galicyjskiego nowej listy kandydatów. Było do przewidzenia, że tym razem nie weźmie się pod uwage i zapewne nie przejdą kandydatury dwóch stosunkowo młodych i gorliwych biskupów: z Tarnowa ks. J. G. Wojtarowicza i z Przemyśla ks. F. K.

30 Tamże, nr 29707/331 z 1847 (wniosek Kancelarii Nadwornej - 2 IX 1847; nominacja cesarska - 18 VIII 1847); nr 12210/867 ex 1848 (kopie bull papieskich).

:31 HHSt. Wien. 3. M. R. 1849. Nr 886 (wniosek hr. Stadiona - 24 III 1849).

32 Tamże. 
Wierzchlejskiego. Obydwaj bowiem w oczach rządu byli wysoce skompromitowani politycznie. Pierwszemu nie chciano przebaczyé postawy, jaką zajął w 1846 i 1848 r., drugiemu natomiast miano za złe „,dwuznaczną postawę w 1848 r." i przynależność do Lwowskiej Rady Narodowej. W stosunku do pierwszego już w $1846 \mathrm{r}$. gubernator Stadion posłał do Wiednia wniosek, by usunąc go z biskupstwa w Tarnowie, a w stosunku do drugiego ,miano go surowo napomnieć na przyszłość” 33.

Odpowiednią listę kandydatów przedstawił 16 XII 1848 r. gubernator Galicji Wacław Zaleski i posłał ją do Wiednia. Obejmowała ona trzy nazwiska: (1) biskupa przemyskiego F. K. Wierzchlejskiego, (2) kanonika lwowskiego i radcę gubernialnego Antoniego Manastyrskiego oraz (3) prepozyta kapituły oraz wikariusza kapitulnego lwowskiego ks. Kajetana Żmigrodzkiego. Nie była to jednak jedyna lista z Galicji. Nie pytano wprawdzie jeszcze o zdanie ordynariuszów pozostałych diecezji galicyjskich, ale listę taką przedstawił również hr. Agenor Gołuchowski, który z dniem 15 I 1849 r. miał objąć urząd namiestnika w Galicji. Jego lista obejmowała również trzy nazwiska, ale zupełnie różne od poprzednich; byli to: (1) ks. Łukasz Baraniecki kanonik lwowski, (2) ks. Józef Hoppe prepozyt infułat kapituły przemyskiej i (3) ks. Julian Zagórski profesor teologii na Uniwersytecie Lwowskim.

Obydwie listy, zostały przesłane do Wiednia i dostały się do rąk hr. Stadiona, który jako minister spraw wewnętrznych miał wydać opinię o kandydatach i zredagować ostateczny wniosek w tej sprawie. On téz położył werdykt na wszystkie kandydatury W. Zaleskiego. Odnośnie biskupa Wierzchlejskiego hr. Stadion motywował odrzucenie jego kandydatury tym, że ,należał do Rady Narodowej w 1848 r.”, zaś kandydaturę ks. A. Manastyrskiego skwitował stwierdzeniem, że ,,jest chorowity". Nie podobał się mu również ks. K. Żmigrodzki, jako że zbyt mocno był powiązany $z$ restauracją katolicką w Austrii.

Podjął natomiast kandydaturę ks. Łukasza Baranieckiego, wysuniętą przez A. Goluchowskiego. Był to kapłan archidiecezji lwowskiej (ur. 1798), bez stopni akademickich, pracujący od $1822 \mathrm{r}$. wyłącznie w duszpasterstwie jako proboszcz w Hodownicy, Źórawnie i przy archikatedrze lwowskiej. Był on osobiście znanym hr. Stadionowi z jego czasów lwowskich. Toteż we wniosku do Franciszka Józefa I z dnia 24 III 1849 r. minister pisał: „,kanonik Baraniecki jest mi osobiście znany z czasów mojej slużby na stanowisku gubernatora Galicji; jest to mąż znany z szerokiego wykształcenia i wielkiego doświadczenia w zakresie szkolnictwa". Podkreślał też - co trzeba szczególnie zaznaczyć dla tego okresu - że ks. Baraniecki ,umie dobrze współżyć z greko-katolikami”, a w 1848 r. ,oka-

33 Tamże, Cabinetts - Acta 1850 nr 1412 (protokół posiedzenia Rady Ministrów z 9 IV 1850). 
zał się prorządowy - als Mann der Regierung". Przeto, pominąwszy inne kandydatury hr. Gołuchowskiego, hr. Stadion nie tylko wysunął kandydaturę ks. Baranieckiego na czołowe miejsce, ale wprost o nią prosił cesarza. Istotnie, ta właśnie kandydatura została zaakceptowana przez cesarza Franciszka Józefa I; dnia 30 III 1849 r. cesarz zamianował ks. Ba. ranieckiego metropolitą we Lwowie, a papież Pius IX bullą Divina disponente gratia z 29 IX 1849 r. prekonizowal go na to stanowisko ${ }^{34}$. Był to kandydat bardzo lojalny wobec rządu austriackiego, niemniej jako Polaka po tak długiej przerwie Lwów przyjął z niekłamaną radością. Powstale w tym okresie ody łacińskie i polskie na jego cześć podkreślają z całym naciskiem, że jest „nasz” i „Polak” ${ }^{35}$. Arcybiskup Baraniecki rozpocząl znów serię metropolitów Polaków we Lwowie.

W Galicji po r. 1850 zgodnie z konkordatem austriackim z r. 1855 oraz z patentem Franciszka Józefa I z dnia 7 V 1874 r. cesarzowi przysługiwało prawo prezenty i nominacji biskupów na wszystkie stolice biskupie - również w Galicji. W stosunku do Krakowa przywilej taki otrzymał cesarz austriacki w bulli papieża Leona XIII Sanctae Apostolicae Sedis z 20 I 1880 r. ${ }^{36}$ Przepisy prawne wymagały od kandydata obywatelstwa austriackiego, odpowiedniej postawy moralnej i obywatelskiej oraz odpowiednich zdolności do piastowania tak ważnego urzędu kościelnego. Kandydatów na stolice biskupie w Galicji wysuwało namiestnictwo we Lwowie, które jednak było zobowiązane zasięgnąc opinii w tym względzie od wszystkich biskupów galicyjskich z danej prowincji kościelnej. Ostateczną listę kandydatów formował sam namiestnik i tę wraz z opiniami i personaliami kandydatów przesyłał do Wiednia. Dalej prowadziło sprawy Ministerstwo Wyznań Religijnych i Oświecenia Publicznego. Na jego prośbę Ministerstwo Spraw Zagranicznych zwracało się do nucjatury apostolskiej w Wiedniu z zapytaniem, czy kandydat będzie acceptabilis dla Stolicy Apostolskiej. W wypadku pozytywnej odpowiedzi cesarz mianował kandydata na wakujące biskupstwo, ale nominacji tej na razie nie ogłaszano. Powiadomione o tym fakcie Ministerstwo Spraw Zagranicznych zwracało się teraz pisemnie w tej sprawie do nuncjatury apostolskiej i po otrzymaniu pozytywnej odpowiedzi, przesyłało nominację ambasadzie austriackiej przy Watykanie. Gdy również z Rzymu nadeszła pomyślna odpowiedź, następowała publikacja nominacji, przeprowadzenie procesu informacyjnego przez nuncjusza wiedeńskiego, prekonizacja papieska i przesłanie bull papieskich nominatowi za pośredni-

34 Allg. Verw. Wien. Alte Kultus Akten. Fasc. 135. Erzbisthum Lemberg. Nr $8175 / 1073$ ex 1849 (wniosek Min. Spr. Wewn. - 1 III 1849); HHSt. Wien. Geistliche - Agentie - Akten. Bischofsernennungen. Fasc. 69 (kopie bull papieskich).

35 Gtos duchownego, czyli , pieśń radosna na pamiatke instalacji J.W.X. Łukasza Baranieckiego arcybiskupa lwowskiego ob. łac. - - dnia 14 stycznia 1850 - Lwów 1850 (druk luźny).

36 B. Kumor, Obsada biskupstwa krakowskiego, s. 350. 
ctwem ambasady austriackiej przy Watykanie. Po prekonizacji papież w każdym wypadku powiadamiał urzędowo o niej cesarza osobrą bulla Gratiae divinae proemium ${ }^{37}$. Tak też w zasadzie przebiegała obsada metropolii lwowskiej po $1850 \mathrm{r}$. Ale tym razem wchodzili w grę tylko polscy kandydaci.

Po 9 latach duszpasterzowania w archidiecezji lwowskiej zmarł arcybiskup Ł. Baraniecki (30 VI 1858). Zgodnie z prawem konkordatowym urzędujący wówczas w Galicji namiestnik hr. A. Gołuchowski zwrócił się w poufnym liście do biskupów w Przemyślu i Tarnowie o nadesłanie na jego ręce listy kandydatów. Biskup przemyski F. K. Wierzchlejski wysunął 3 kandydatów; na pierwszym miejscu umieścił biskupa tarnowskiego Józefa Alojzego Pukalskiego, następnie ks. Leopolda Olcyngera działacza społecznego i proboszcza w Tyczynie, a na trzecim miejscu - ks. Macieja Hirschlera kanonika kapituły lwowskiej i inspektora szkolnego. Najbardziej wszakże zalecał biskupa Pukalskiego jako „męża pobożnego, przystępnego i łagodnego dla kleru i lojalnego wobec dworu cesarskiego".

Biskup tarnowski J. A. Pukalski stwierdzał, że, żaden z kanoników tarnowskich nie nadaje się na biskupa"; był to pogląd bardzo subiektywny i dyktowany zapewne osobistymi przeżyciami w Tarnowie, dokąd przyszedł w 1851 r. po usunięciu przez władze austriackie biskupa J. G. Wojtarowicza, do którego kler i kapituła byli przywiązani. Stąd też biskup Pukalski na swojej liście umieścił tylko nazwisko biskupa przemyskiego F. K. Wierzchlejskiego ,,jako tego, który zna świetnie archidiecezję lwowską".

Ponieważ w 1859 r. hr. A. Gołuchowski odszedł do Wiednia, dlatego w czasie wakansu urzędu namiestnika sprawy prowadził radca nadworny Mosch. On też zaproponował swoją listę kandydatów: (1) biskupa F. K. Wierzchlejskiego z Przemyśla, (2) ks. Adama Jasińskiego rektora seminarium duchownego i kanonika kapituły lwowskiej oraz (3) ks. Marcina Skierczyńskiego rektora seminarium duchownego w Przemyślu. Najbardziej wszakże zalecał biskupa Wierzchlejskiego. Według jego opinii „,nie ma żadnych podstaw, by biskupa Wierzchlejskiego pominąć przy nominacji". Ta też rekomendacja zaważyła i na liście Ministerstwa WRiOP z 16 XI 1859 r. znalazła się kandydatura biskupa Wierzchlejskiego na pierwszym miejscu z najlepszą opinią. Przed 10 laty jego kandydatura została odrzucona, ale teraz w erze konstytucyjnej można było liczyć na jej przyjęcie. Na skutek tych zaleceń Franciszek Józef I w dniu 6 XII 1859 r. zamianował biskupa Wierzchlejskiego metropolitą lwowskim. Prekonizacji na to stanowisko dokonał papież Pius IX na mocy bulli Romani Pontificis (23 III 1860); w dniu 16 IX t. r. nastąpiła uroczysta in-

${ }_{3 \pi}$ HHSt. Wien. P. A. XI. Interna. Liasse LX. Übliche Vorgangsweise bei der Ausübung des Präsentationsrechtes Seines K. und K. Apostolische Majestät. 
tronizacja ks. Wierzchlejskiego na metropolitę lwowskiego ${ }^{38}$. Był to kapłan diecezji tarnowskiej (ur. 1803), który po studiach specjalnych z zakresu Pisma św. na Uniwersytecie Wiedeńskim był profesorem tejże dyscypliny w studium zakonnym najpierw w Kalwarii Zebrzydowskiej, a następnie we Lwowie. W latach $1834-1845$ był proboszczem w Gołogórach koło Lwowa, a następnie kanonikiem kapituły metropolitalnej we Lwowie (1845-1846) i bisgupem przemyskim (1846-1860). Był to obok arcybiskupa A. A. Ankwicza najwybitniejszy metropolita lwowski w XIX stuleciu ${ }^{39}$.

Po śmierci metropolity Wierzchlejskiego kapituła lwowska wybrała wikariuszem kapitulnym biskupa pomocniczego Seweryna Tytusa Morawskiego (18 IV 1884). Był to kapłan archidiecezji lwowskiej, który długie lata pracował jako kanclerz konsystorza metropolitalnego, a od 1862 był kanonikiem kapituły lwowskiej, zaś od 1872 — dziekanem infułatem tejże kapituły. W r. 1881 został biskupem pomocniczym we Lwowie ${ }^{40}$. Zgodnie z obowiązującym prawem namiestnik Galicji hr. Zaleski zasięgnął opinii biskupów z Przemyśla, Tarnowa i Krakowa w sprawie ewentualnych kandydatów na wakującą stolicę metropolitalną.

Biskup przemyski Łukasz Solecki wysunął tylko 2 kandydatury: na pierwszym miejscu wymienił wikariusza kapitulnego archidiecezji i biskupa pomocniczego lwowskiego S. T. Morawskiego, na drugim zaś biskupa krakowskiego Albina Dunajewskiego. Trzeciej kandydatury nie postawił. Biskup tarnowski J. A. Pukalski tym razem poprawił się i dostrzegł wśród kleru diecezjalnego odpowiednich kandydatów na przyszłego metropolitę lwowskiego. Trzej jego kandydaci byli kapłanami diecezji tarnowskiej. Na pierwszym miejscu umieścił światłego i dobrego prawnika ks. Wawrzyńca Gwiazdonia, prepozyta infułata kapituły tarnowskiej: drugie miejsce zajął poseł do Rady Państwa w Wiedniu i proboszcz w Kolbuszowej - ks. Ludwik Ruczka, a trzecie - kanonik honorowy tarnowski i proboszcz w Tucjowie - ks. Jan Rybarski. Żaden jednak z tych kandydatów nie miał wejść na listę namiestnika.

Biskup krakowski A. Dunajewski nie przygotował odrębnej listy, ale przy spotkaniu z namiestnikiem Zaleskim oświadczył, że sam arcybiskupstwa lwowskiego nie przyjmie. Przy okazji tego spotkania ustalono też wspólnie nową listę kandydatów, którą namiestnik przesłał do Wiednia.

38 HHSt. Wien. 17 K. Z. 1859. Nr 3750-3999. Kabinetts - Kanzlei - Akten. Nr 3952/1859 (wniosek Ministerstwa WRiOP - 16 XI 1859); Geistliche Agentie Akten. Bischofsernennungen. Fasc. 155 Wierzchlejski 1860 (kopie bull papieskich); Allg. Verw. Wien. Ministerium für Kultus Unterricht. Kultus Akten. Fasc. 36. Nr 912 (kopia nominacji cesarskiej).

39 W. Sarna, Biskupi przemyscy obrządku łacińskiego 1624-1900. T. 2, Przemyśl 1910 , s. $569-577$.

${ }_{40}$ B. Kumor, Morawski Seweryn Tytus, [w:] Polski Stownik Biograficzny 20 S. $740-743$. 
Terno ustalone na tej liście wymieniało: (1) biskupa S. T. Morawskiego, (2) biskupa przemyskiego Eukasza Soleckiego i (3) kanonika przemyskiego Jana księcia z Kozielska Puzynę. Najbardziej wszakże zalecano biskupa Morawskiego jako „faktycznie od lat zarządzającego archidiecezją” i „cieszącego się wielkim szacunkiem wśród ziemiaństwa i kleru”. Podkreślano też, że ,jest bardzo tolerancyjny wobec katolików obrządku grecko-katolickiego". Wniosek namiestnika poparło Ministerstwo WRiOP (12 II 1885), na skutek czego cesarz Franciszek Józef I w dniu 15 II 1885 r. zamianował biskupa Morawskiego arcybiskupem metropolitą lwowskim. Prekonizacja papieska nastąipiła już 27 III t. r., a uroczysta intronizacja 17 maja t. r. ${ }^{41}$

Wakans stolicy metropolitalnej we Lwowie po śmierci arcybiskupa Morawskiego (2 V 1900) zbiegł się z wakansem stolic biskupich w Przemyślu i Tarnowie. Z łacińskich stolic biskupich obsadzony był tylko Kraków, gdzie od 1895 r. duszpasterzował książę biskup Jan Puzyna. Dawało to niewątpliwie większe szanse dla kandydata namiestnika Galicji hr. Pinińskiego, jako że listę ewentualnych kandydatów na wakującą metropolię mógł zgłosić tylko biskup krakowski. Drugi ważny problem, który był żywo dyskutowany w r. 1900 i znalazł wyraz we wniosku namiestnika Pinińskiego była sprawa podziału archidiecezji lwowskiej na diecezję tarnopolską i ewentualnie bukowińską, a także podział diecezji przemyskiej na diecezję rzeszowską i przemyską ${ }^{42}$. Rzeczywiście obydwie diecezje były nie tylko rozległe terytorialnie, ale i bardzo ludne. Archidiecezja lwowska obejmowała w r. 1900267 placówek duszpasterskich, 385 kapłanów diecezjalnych i 64 zakonnych oraz 840182 wiernych; na Bukowinie nadto dawał o sobie znać problem narodowościowy o charakterze niemieckim ${ }^{43}$. Diecezja przemyska była najludniejszą diecezją w Galicji i w r. 1907 liczyła 298 placówek duszpasterskich, 446 księży diecezjalnych i 7 zakonnych oraz 1150723 wiernych ${ }^{44}$. Toteż dyskutowany problem podziału obydwóch diecezji nalazł wyraz również we wniosku namiestnika Pinińskiego, skierowanym przed 25 V 1900 r. do Wiednia. Namiestnik postulował, by w czasie wakansu obydwóch diecezji dokonać ich podziału ze względów zarówno religijno-kościelnych, jak i socjalno-radykalnych.

41 HHSt. Wien. 3 Z. K. 1885. Nr 598 (wniosek Ministerstwa WRiOP o mianowanie biskupa Morawskiego arcybiskupem lwowskim - 12 II 1885); Allg. Verw. Wien. Ministerium für Kultus und Unterricht. Kultus Akten. Fasc. 36. Nr 63 ex 23 XII 1885; nr 12355 z 6 VII 1885 i nr 11645 z 27 VI 1885 (dokumenty związane z nominacją na arcybiskupstwo).

42 M. Tarnawski, Józef Bilczewski. Krótki rys życia i prac, Lwów 1924, s. 34 n.; B. Kumor, Granice metropolii i diecezji polskich 968-1939, Lublin 1969-1971 (odb. z ABMK) s. 387 n.

${ }_{43}$ Catalogus universi venerab. cleri - - archidioecesis Leopoliensis rit. lat. p. a. D. 1901, Leopoli 1901, s. 248 n.

${ }_{44}$ Schematismus dioecesis Premisliensis rit. lat. p. a. D. 1908, Premisliae 1907, s. $336 \mathrm{n}$. 
Jako przyszłe stolice biskupie hr. Piniński wymieniał Tarnopol i Rzeszów. Uposażenie obydwóch nowych biskupstw miały częściowo stanowić majątki biskupstw obrządku łacińskiego we Lwowie i Przemyślu, a częściowo pochodzić z Funduszu religijnego. We wniosku znalazł się również szeroko rozpracowany problem Bukowiny, gdzie mieszkało ok. 80 tysięcy katolików. Namiestnik proponował, by tu utworzyć odrębny wikariat generalny zależny od Lwowa. Sprawy te uprzednio zostały uzgodnione z nuncjuszem papieskim w Wiedniu i Ministerstwem WRiOP (dr A. Hartel) ${ }^{45}$.

Ale powróćmy do sprawy obsady arcybiskupstwa. Namiestnik na ten temat pisał, że ,z chwilą śmierci arcybiskupa Morawskiego byłem natychmiast zdecydowany zaproponować ks. Bilczewskiego na następcę, lecz zdawałem sobie sprawę, że propozycja, co do której trzeba było wedle zwyczaju zażądać też opinii innych arcybiskupów kraju i księcia biskupa krakowskiego, mogła natrafić na silną opozycję. Młody profesor, który nie doszedł jeszcze lat 40 mógł się wydawać sferom decydującym w Wiedniu kandydatem nie do przyjęcia, a i w kraju też wybór duchownego tak młodego i nieznanego w szerszych sferach mógł zadziwić i spotkać się z niechęcią i uprzedzeniami. Wtedy to, wstrzymując się na razie z propozycją, wpadłem na myśl, która w dalszym toku okazała się nader szczęśliwą. Zwierzyłem się ze swoim zamiarem najprzód ówczesnemu rektorowi Lwowskiego Uniwersytetu, memu przyjacielowi prof. Abrahamowi, a następnie jeszcze kilku innym profesorom Wszechnicy, z którymi mnie bliższe łączyły węzły zażyłości. Myśl poruszona wywołała jak najżywszy odźwięk sympatii w uniwersyteckich sferach i Uniwersytet Lwowski zdecydował się na krok, który, jak sądzę, stał się dla przyszłego zamianowania ks. Bilczewskiego arcybiskupem wydarzeniem wprost decydującym. Oto, pomimo iż wybór rektora na następny rok szkolny nie przypadał według kolei na fakultet teologiczny, a tym mniej na jednego z najmłodszych na tymże fakultecie profesorów, jakim był wówczas ks. Bilczewski, odstąpiono wyjątkowo od owej tradycyjnej kolejności i jednomyślną uchwałą grona ,elektorów” wybrano ks. Bilczewskiego rektorem. Uniwersytet przez to chciał ułatwić mu zamierzoną propozycję, a zarazem dać wyraz czci i gorącego uznania dla męża, któremu wkrótce miało być przeznaczonym opuścić katedrę uniwersytecką dla zajęcia najwyższego stanowiska kościelnego w kraju" ${ }^{46}$.

Ze względu na osierocenie diecezji galicyjskich listy kandydatów przygotowali tylko książę biskup krakowski J. Puzyna i namiestnik hr. L. Piniński oraz metropolita lwowski obrządku ormiańskiego I. M. Isako-

4.5 HHSt. Wien. 3 Z. K. Nr 2849/900 (wniosek Ministra WRiOP dra A. Hartela w sprawie obsady arcybiskupstwa lwowskiego ob. łac. - 15 X 1900).

${ }_{46}$ M. Tarnawski, jw., s. 17 n. 
wicz ( $†$ 1901); był to pierwszy i ostatni wypadek, że przy obsadzie łacińskiej stolicy arcybiskupiej we Lwowie listę kandydatów przysłał również arcybiskup ormiański. Lista biskupa Puzyny wymieniała 3 kandydatury: (1) biskupa pomocniczego lwowskiego Józefa Webera, (2) kanonika kapituły lwowskiej Leona Wałęgę i (3) rektora Uniwersytetu Lwowskiego i profesora dogmatyki specjalnej ks. Józefa Bilczewskiego. Natomiast lista arcybiskupa ormiańskiego I. M. Isakowicza obejmowała 5 kandydatów. Obok trzech wyżej wymienionych proponował nadto wikariusza kapitulnego archidiecezji, jednocześnie prepozyta infułata kapituły metropolitalnej ks. Feliksa Zabłockiego, oraz przebywającego na wygnaniu we Lwowie, byłego biskupa wileńskiego i arcybiskupa tytularnego Karola Hryniewieckiego.

Ale opinia namiestnika Pinińskiego była wyraźnie skierowana przeciwko wszystkim tym kandydatom $z$ wyjątkiem ks. Józefa Bilczewskiego. O biskupie J. Weberze napisał, że ,nie ma potrzebnej energii na tak wysokie stanowisko"; ks. Leonowi Wałędze zarzucił, że „ze względu na jego konfliktowe stosunki z klerem ruskim" i „w interesie pokoju między obydwoma obrządkami" nie można go brać pod uwagę. Ks. F. Zabłocki, zauważał dalej Namiestnik, jeszcze w 1895 r. złożył prośbę, by jego osoby nie brać pod uwagę przy obsadzaniu stanowiska biskupa pomocniczego we Lwowie, a nadto ma 70 lat i stąd ,jego osoba nie może wchodzić w rachubę". Dezaprobata zaś byłego biskupa wileńskiego K. Hryniewieckiego miała źródło w tym, że jeszcze w r. 1893 Ministerstwo Spraw Zagranicznych w Wiedniu odrzuciło jego kandydaturę ze względu na stosunki $z$ Rosją, a nadto jego zdrowie jest bardzo słabe ${ }^{47}$.

$\mathrm{Na}$ liście kandydatów popieranych przez namiestnika pozostał jedynie ks. J. Bilczewski, wymieniony $\mathrm{w}$ terno namiestniczym na pierwszym miejscu, a w dwóch pozostałych - na miejscu trzecim. Pochlebna opinia biskupa Puzyny o ks. Bilczewskim upewniła hr. Pinińskiego w powziętym zamiarze. Podczas swego pobytu w Wiedniu poruszył sprawę tej kandydatury w rozmowie ustnej z cesarzem i przedstawił ją także ówczesnemu ministrowi WRiOP Hartlowi, a ci okazali się dla tej propozycji bardzo przychylni. Po powrocie z Wiednia namiestnik skontaktował się z ks. Bilczewskim. „Chcę podać do wiadomości Księdza Profesora - pisał 7 VIII 1900 r. - że po bardzo dojrzałym i gruntownym namyśle zdecydowałem się stanowczo zaproponować Najjaśniejszemu Panu zamianowanie Ks. Profesora arcybiskupem ritus latini lwowskim. Mówiłem już

${ }_{47}$ Zob. przypis 45 - opinia o ks. L. Wałędze: „Dr Wałęga hat seine Studien in Rom zurückgelegt, war Universitätsprofessor in Lemberg, ist ein gebildeter im Interesse der sittlichen und materiallen Hebung der Handwerkerjugend wirkender Priester, seine Ernennung wird aber wegen seines wenig concilianten Vorhaltens dem ruthenischen Clerus gegenüber im Interesse des Friedens unter den Riten als nicht rathsam empfohlen". Tam też załączone pozostałe opinie o innych kandydatach. 
o tym tak z cesarzem, jak i z ministrem Hartlem i znalazłem ich, o ile sądzić mogę, dla tej myśli zupełnie przychylnie usposobionych. Z mej jednak strony uważam jeszcze za rzecz konieczną zwrócić się z jak najusilniejszą prośbą do samego Księdza Profesora o podjęcie się tych ciężkich wprawdzie, ale wielce doniosłych i zaszczytnych obowiązków. Liczę na pewno na to, że Ksiądz Profesor podoła temu stanowisku doskonale i że Jego działalność błogie skutki będzie mieć dla dobra Kościoła i ludności...". W liście z dnia 11 VIII t. r. ks. Bilczewski wyraził faktycznie zgodę na proponowany mu urząd ${ }^{48}$. We wniosku posłanym do Wiednia przed 15 X $1900 \mathrm{r}$. prosił hr. Pinińskiego wprost o nominację na Lwów ks. Józefa Bilczewskiego, chociaż nie pominął kandydatur wspomnianych uprzednio. Ale tylko o ks. Bilczewșkim wydał niezwykle piękną opinię. Po krótkim szkicu jego życia, w którym podkreślił jego studia uniwersyteckie w Wiedniu, Rzymie i Paryżu, pisał, że ,na polu naukowym ks. J. Bilczewski jest bardzo czynny i znany w świecie jako uczony wysokiej klasy. Działa on również na polu społecznym, zwłaszcza od 1898 r. kiedy został członkiem Krajowej Rady Szkolnej jest świetnym znawcą zagadnień szkolnictwa w Galicji oraz spraw gospodarczo-politycznych tego kraju". Na posiedzeniu Rady Ministrów w dniu 15 X 1900 r. przy omawianiu kandydatury ks. Bilczewskiego minister Hartel nazwał go ,niezwykle wyróżniającym się kandydatem” i wyrażał nadzieję, że „On na przyszłość będzie mógł rozwiązać cały szereg trudnych zagadnień". Stanowisko ministra Hartla poparła cała Rada Ministrów. Toteż we wniosku do cesarza w dniu 23 X 1900 r. ks. Bilczewski był właściwie jedynym kandydatem na metropolitę lwowskiego. Zgodnie też z wnioskiem nastąpiła również nominacja cesarska w dniu $30 \mathrm{X}$ t. r. ${ }^{49}$. Dnia 9 listopada ks. J. Bilczewski złożył urząd rektora Uniwersytetu Lwowskiego, 12 listopada odbył się jego proces informacyjny i złożenie przysięgi na ręce nuncjusza apostolskiego Tallianiego w Wiedniu. Dnia 17 XII t. r. papież Leon XIII bullą Divina disponente gratia prekonizował ks. J. Bilczewskie--

48 M. Tarnawski, jw., s. $21 \mathrm{nn}$.

49 Zob. przypis 45 - opinia o ks. Bilczewskim: „Der vom Stadthalter vorgeschlagene Dr Bilczewski ist 1860 geboren, empfing 1884 die Priesterweihe, oblag sodann den hohören Priesterstudien in Wien, Rom und Paris, habilitierte sich 1890 als Privatdocent an der Krakauer Universität. Wurde mit All. Ent. vom 14 Januar 1891 zum ausserordentlichen, mit All. Ent. vom 28 Januar 1895 zum ordentlichen Professor des speciellen Dogmatik an der Lemberger Universität ernannt. Auch auf dem wissenschaftlichen Gebiete rastlos thätig und in der gelehrten Welt weit bekannt, wirkt Dr. Bilczewski auch auf den anderen Gebieten des öffentlichen Lebens und zwar seit 1898 als Mitglied des galizischen Landesschulrathes, wobei er sich nicht nur als ausgezeichneter Kenner des Schulwesens, sonder auch als ein in politischen Fragen vorsichter Mann erwiesen hat. Der Cultusminister bezeichnet ihm auch als den geeignetesten Candidaten, glaubt in ihm einen objectiwen Mann bei künftiger Lösung der ... erwähnten Fragen zu finden und erlaubt sich sohin im Einvernehmen mit dem Minister Dr. Piętak und mit Zustimmung des Ministerialrathes (Sitzung vom 15 October 1900) den nachstehenden Entwurf der All. Entschliessung an zu unterbreiten". 
go na arcybiskupa metropolitę obrządku łacińskiego we Lwowie. Konsekracja i intronizacja w archikatedrze lwowskiej nastąpiła w dniu 20 I 1901 r. Konsekracji dokonał książę biskup krakowski J. Puzyna w asyście metropolity unickiego Andrzeja Szeptyckiego i biskupa przemyskiego Józefa Sebastiana Pelczara 50. Z objęciem rządów przez arcybiskupa J. Bilczewskiego rozpoczął się najświetniejszy pontyfikat w 600-letnich dziejach archidiecezji i metropolii lwowskiej, ale do podziału archidiecezji na trzy diecezje nie dopuścił nowy Metropolita.

50 HHSt. Wien. Geistliche Agentie Akten. Bischofsernennungen 205. J. Bilczewski (kopie bull papieskich); M. Tarnawski, jw., s. $25 \mathrm{n}$.

DIE BESETZUNG DER LEMBERGER METROPOLIE LAT. RIT. IN DEN 1772-1918

\section{Z U S A M M E N F A S S U N G}

Das Interesse des österreichischen Regierung gilt sehr früh der Besetzung der Lemberger Metropolie und der Bischofssitze in Galizien. Schon 1774 verlangte der Gubernator Galizien Graf Auersperg vom lemberger Erzbischof W. H. Sierakowski eine Information hinsichtlich des rechtlichen Brauchs, der bei der Bischofswahl in Lemberg und Przemyśl massgebend war. Diese Information benötigte der Wiener Hof, weil die Kaiserin in den Bereich des Kollatorsrechts des polnischen Königs eingehen solte. Indem man den bisherigen Brauch der Bischofswahl eines königlichen Nominaten durch das Domkapitel missachtete, beanspruchten die österreichischen Kaiser das Prinzip einer Nominierung des Metropoliten und der Bischöfe in Galizien, ohne Rom und das Domkapitel um Einwilligung zu befragen. Von da her sah die Besetzung der Bischofssitze im Gebiete des österreichischen Besetzungsteiles folgend aus.

Die Kandidaten für die Bischofssitze wurden von Lemberger Gubernium gestellt. Dieses übersandte eine Kandidatenliste zusammen mit Gutachten und Personalienangaben betreffst der Kandidaten der Wiener Geistlichen Hofskommission. Die Kommision stellte eine entgültige Kandidatenliste auf zusammen mit ihrem eigenen Gutachten und dem Gutachten des Guberniums. Erst jetzt erfolgte die kaiserliche Nominierung und ihre Verlautbarung. Der Nominat wendete sich sodann an den päpstlichen Nuntius in Wien um die Durchführung des Informationsprozesses und an die österreichische Bootschaft beim Vatikan um die Aufsicht über Prekonisation auf dem päpstlichen Konsistorium. Wenn der Kandidat keine Bischofsweihe hatte, war en gezwungen sich binnen von drei Monaten zu empfangen. Von dem Zeitpunkt der Prekonisierung des Metropoliten bzw. des Ordinarius, versandte der Papst im einemjeden Falle die Bulle an den Kaiser. Nach der allgemeinen Besprechung der Besetzungsprozedur von Bischofssitzen berichtet der Verfasser in Details über die Wahlumstände der einzelnen Lemberger Metropoliten von 17721918. Die Vakanzeitabschnitte auf dem Lemberger Erzbischöflichen Stuhl hielten 
nicht lange an. In den Jahren von 1812-1848 wurde dieser Bischofssitz mit Kandidaten tschechischer oder deutscher Herkunft besetzt.

Das Recht der Präsentation und Ernennung der Bischöfe durch den Kaiser würde auch durch staatliche Gesetzgebung und durch das österreichische Konkordat von 1855, sowie das kaiserliche Patent Franz Joseph I 1874 bestätig. Die Rechtsvorschriften verlangten vom Kandidaten das österreichische Bürgerrecht, eine entsprechende moralische und bürgeliche Einstellung, sowie entsprechende Fähigkeiten zur Übernahme eines kirchlichen Amtes.

In den Jahren nach dem Konkordat kam es dennoch zu bedeutenden Meinungsverschiedenheiten bei der Aufstellung der Namenslisten von Kandidaten für freigewordene Bischofsstühle. Das letzte Wort hatte zwar der Stellvertreter Galiziens, aber nach pflichtgemässer Beratung mit allen Bischöfen der kirchlichen Provinz. Praktisch sah das so aus, dass die genannten Bischöfe ihre Kandidatenlisten austellen und dem Stellvertreter übersandten. Das Ergebnis? Im hier besprochenen Zeitabschnitt der Unfreiheit des polnischen Volkes ernannten die österreichischen Behörde zu Metropoliten der lateinischen Erzdiözese Lemberg sechs Nicht-Polen und sechs Kandidaten, die aus dem galizischen Klerus stammten. 